\title{
Application of Project Based Learning Models in Improving Creative Thinking of Students at Physics Lessons in SMA Bandar
} Baru

\author{
Muchsin, Mariati \\ University of Jabal Ghafur, Indonesia \\ muchsin@unigha.ac.id,mariati@unigha.ac.id
}

\begin{abstract}
The ability to think creatively is necessary given that today science and technology are developing very rapidly and allows anyone to be able to obtain information quickly and easily with abundance from various sources and anywhere in the world. This has resulted in rapid changes in the order of life as well as global changes in life based on developments in the era of the industrial revolution 4.0 where communication skills and skills are the main focus. If they are not equipped with the ability to think creatively, they will not be able to process assess and retrieve the information needed to face these challenges. This study uses quantitative research methods aimed at improving the creative thinking of physics students by using the Project Based Learning learning model. The types of instruments used in this study include Observation Sheets, LKPD sheets which are oriented towards the 2013 curriculum, creative thinking test instruments and learning implementation instruments. The results of this study can be concluded that there was an increase in the ability to think creatively after the Project Based Learning model was applied. The average $n$-gain acquisition in experimental class I was 0.75 and classified in the high category and in experimental class II was 0.77 and classified in high category, with an average acquisition of $n$-gain values of both classes of 0.76 with a high category.
\end{abstract}

\section{Keywords}

application; project based learning models; creative thinking; SMA Bandar Baru

\section{Introduction}

The focus of project-based learning lies in the core principles and concepts of a scientific discipline, involving students in investigating problem solving and other meaningful task activities, giving students the opportunity to work autonomously in constructing their own knowledge, and reaching its peak to produce products real. Projectbased learning has great potential to provide more interesting and meaningful learning experiences for students (Wena, 2013). Creative abilities are abilities that are essential for life, work, and function effectively in all other aspects of life. Research and various opinions about it, have become the topic of conversation in the last ten years (Patrick, 2000).

The project-based learning model has the following characteristics: a) Students make decisions about a framework, b) Problems or challenges are presented to students, c) Students design processes to determine solutions to problems or challenges that are proposed, d) Students are collaboratively responsible for accessing and managing information to solve problems, e) The evaluation process is carried out continuously, f) Students periodically reflect on activities that have been carried out, g) The final product of learning activities will be evaluated qualitatively, h) The learning situation is very tolerant of mistakes and change 
(Kemendikbud, 2014). The above opinion, it can be concluded that the project-based learning model has the characteristics of the existence of problems or challenges raised to students, provide a more interesting and meaningful learning experience for students, produce tangible products, and the evaluation process is carried out continuously.

Global issues that are sustainable in the industrial era 4.0, which requires universities to take part in the current Process, Input, Output and Outcome, one that is suitable for sustaining this project-based continuous learning is the educational approach which focuses on creative thinking, problem solving, and interaction between students and peers to create and use knowledge in the current digital era.

Creative thinking is a process that is used when we bring in / come up with a new idea (Siswono, 2006). It combines ideas that have not been done before. In general, creative thinking is triggered by challenging problems. The ability to think creatively in problem solving standards by NCTM (2000), including implementing and adjusting various strategies in solving problems.

The ability to think creatively is necessary given that today science and technology are developing very rapidly and allows anyone to be able to obtain information quickly and easily with abundance from various sources and anywhere in the world. This resulted in rapid changes in the order of life and global changes in life. If it is not equipped with the ability to think creatively, it will not be able to process assess and take the information needed to face these challenges. Physics learning really needs a level of creative thinking in explaining concepts, physics learning has abstract concepts that really need creative thinking in solving complex problems to be simple (Muchsin, 2017). Therefore the ability to think creatively is an important ability in learning physics.

Project Based Learning is a learning model that uses problems as a first step in integrating new knowledge based on real experience (Morrison, et al., 2012). Project Based Learning is carried out systematically which involves students in learning attitudes, knowledge, and skills through investigations in product design. Project Based Learning is an innovative learning model, which emphasizes contextual learning through complex activities. The implementation of Project Based Learning gives students the opportunity to think critically and be able to develop their creativity through developing initiatives to produce tangible products in the form of goods or services.

Based on observations and interviews that have been conducted with grade XI teachers of SMA Negeri 1 Bandar Baru and SMA Negeri 2 Bandar Baru, it is found that there are still many problems faced by both teachers and students in the learning process, especially in physics. For example, students get bored easily when receiving lessons, are easily drowsy, talk to their friends outside the material being discussed in learning, teachers sometimes only focus on one student so that other students feel neglected. Besides that, students still consider physics to be one of the subjects that is considered very difficult to learn because of the many formulas that must be understood. This assumption is proven by students' opinion that physics lessons must master all formulas and lessons that are boring to learn. Teachers have difficulty in focusing students to be active in learning, and teachers are less creative in determining models / strategies that are appropriate to the material, thus making students' creativity not develop.

The learning process in the classroom teachers often use the book media only with conventional learning models so that the opportunity for students to think critically and act creatively is lacking. Physics learning activities that emphasize practical work have not been implemented well, learning activities are still one-way in which the teacher becomes the center of attention of students. In addition, the presence of inadequate teaching aids in the 
laboratory, so learning physics that demands learning in a real-world context becomes difficult to apply. Searching through the documents of the learning outcomes carried out shows that the scores obtained by students of SMA Negeri 1 Bandar Baru during the physics exam were still low. Based on the Minimum completeness Criteria (KKM) that has been set, namely 75 .

\section{Method}

This study uses quantitative research methods aimed at improving the creative thinking of physics students by using the Project Based Learning learning model. The research was carried out in Bandar Baru Subdistrict SMA namely SMA Negeri 1 Bandar Baru and SMA Negeri 2 Bandar Baru. The population in this study were all high schools in Bandar Baru Subdistrict which consisted of SMA Negeri 1 Bandar Baru and SMA Negeri 2 Bandar Baru with a total of 532 learners and 10 classes. The search results obtained by the sample in this study were 23 students of experimental class I and 24 students of experimental class II who came from high schools in Bandar Baru District.

The types of instruments used in this study include Observation Sheets, LKPD sheets which are oriented towards the 2013 curriculum, creative thinking test instruments and learning implementation instruments. Observation sheet to measure students' creativity in the learning process. This observation sheet processing is done by scoring for all aspects of creativity based on indicators. Observation sheet is filled by observer during the research process. The test is used to measure students' creative thinking.

The type of research used is Quasi experimental. The design used is the nonequivalent control group design (Arifin, 2008). The study design is presented in Table 1.

Table 1. Non-equivalent Control Group Design

\begin{tabular}{cccc}
\hline Kelompok & Pretest & Treatment & Postest \\
\hline Exsperiment I & $0^{1}$ & $\mathbf{X}$ & $0^{2}$ \\
\hline Exsperiment II & $0^{3}$ & $\mathbf{X}$ & $0^{4}$ \\
\hline & & & (Arifin, 2008)
\end{tabular}

Data collection techniques used to determine the effect of the Project Based Learning model on students' creative thinking, namely using test instruments and LKPD sheets that were directly dataed by observers during the research. The data analysis technique for researchers uses the normalized N-Gain test (N-gain) with the equation (Sundayana, 2014).

$$
\mathrm{N}-\text { gain }=\frac{\mathrm{S}_{\text {post }}-\mathrm{S}_{\text {pre }}}{\mathrm{S}_{\max }-\mathrm{S}_{\text {pre }}} \times 100 \%
$$

The research process includes several stages, namely the preparation phase, the stage of data collection, and the analysis phase. The preparation phase includes the stages of preparing learning tools such as Syllabus, Learning Implementation Plan (RPP), Student Worksheet (LKPD), observation sheet and test questions to measure students' creative thinking. Based on the data of Creative Thinking test values, obtained the highest value data (Xmax), the lowest value (Xmin), the average value (X) in the experimental class and control class. The results of research data on the value of creative thinking of students in the experimental class I and experimental class II can be seen in Table 2. 
Table 2. Data Description of Student's Creative Thinking Value

\begin{tabular}{llllll}
\hline \multirow{2}{*}{ No } & \multirow{2}{*}{ School } & \multirow{2}{*}{ Class } & Ideal & \multicolumn{2}{l}{ Criteria } \\
\cline { 6 - 6 } & & & Value & medium & high \\
\hline 1 & SMA Negeri 1 Bandar Baru & Eksperimen I & 100 & 8 & 15 \\
\hline 2 & SMA Negeri 2 Bandar Baru & Eksperimen II & 100 & 6 & 18 \\
\hline
\end{tabular}

The initial ability data used in this study is the result data from the student's initial test before being given treatment. Initial tests are given to find out the homogeneity and normality of students' initial creative thinking in the experimental class I and experimental class II. Preliminary test data indicate that the initial creative thinking skills in both classes are the same. The average value of experimental class I is 58 and experiment II is 55 . The initial test of students in both classes has a low score. From the homogeneity test the initial test data that has been done is obtained F-calculated value which means the initial test data of the two classes is homogeneous. The final capability data obtained in this study is the data after it is given treatment. Test results have shown an increase in the average final test that is higher than before. The average grade of experimental class I and experiment II is 90 . The final test of students in both classes has increased from the initial test.

\section{Discussion}

Improving Students' Creative Thinking in Bandar Baru Subdistrict High School This study aims to determine the improvement of the creative thinking of physics students by using the Project Based Learning learning model. Before giving treatment to students, the instrument has been validated by experts with good categories. Data about the results of the ability of students before and after treatment is obtained through the initial test and final test. The creative thinking ability of students before and after treatment is seen from the initial and final test scores presented in Figure 1 below.

Achievement Criteria for Increasing Creative Thinking

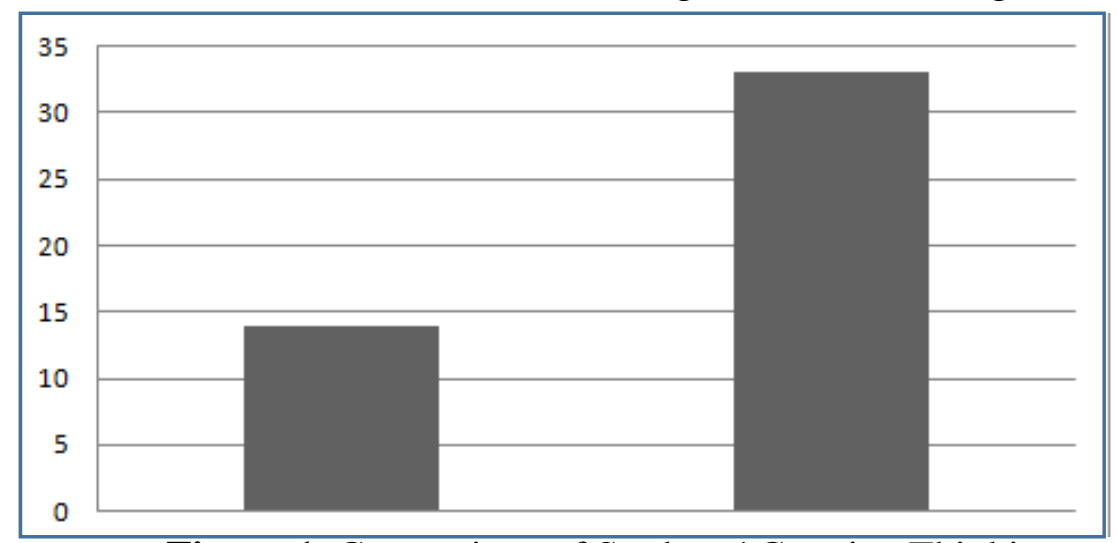

Figure 1. Comparison of Students' Creative Thinking

Based on the bar diagram in Figure 1 above, there are two categories based on the calculation of the n-gain value. A total of 14 students get a medium category with a range of gain scores of $0.70 \geq \mathrm{g}>0.30$ and as many as 33 students get a high category with a range of gain scores of $1.0 \geq \mathrm{g}>0.70$. The results of the increase in the achievement of creative thinking can be seen with the results of the normalized n-gain analysis presented. It can be seen that the average acquisition of n-gain in experimental class $I$ is 0.75 and is classified in 
the high category and in experimental class II is 0.77 and is classified in the high category, with an average acquisition of n-gain values for both classes by 0.76 with the high category. This proves that in learning with the application of the Project Based Learning model students are actively involved in learning so that they are able to associate new information with the information they already have. Students will also more easily store information into long-term memory because students are actively involved in learning.

This will be easier because students find the concepts being learned by using their own learning methods but still with guidance from the teacher. This is in line with the theory of constructivism learning where students themselves must personally find and apply information, check new information compared to information already possessed (Nur, et al, 2008). This is supported by Tantri \& Ari Atriya, 2015 which states that the application of a scientific approach can improve student learning outcomes in knowledge competencies. Some of the results of the analysis of the achievement of students' knowledge competencies can be stated that the application of learning based on scientific approaches in science learning is proven to help in improving learning outcomes in knowledge competencies.

\section{Conclusion}

The results of this study can be concluded that there is an increase in the ability to think creatively after applying the Project Based Learning model. The results of the increase in the achievement of creative thinking can be seen with the results of the normalized n-gain analysis presented. It can be seen that the average acquisition of n-gain in experimental class I is 0.75 and is classified in the high category and in experimental class II is 0.77 and is classified in the high category, with an average acquisition of n-gain values for both classes by 0.76 with the high category. This proves that in learning with the application of the Project Based Learning model students are actively involved in learning so that they are able to associate new information with the information they already have. Students will also more easily store information into long-term memory because students are actively involved in learning.

\section{References}

Arifin, Zainal. 2008. Metodelogi Penelitan Pendidikan, Surabaya: Lentera Cendikia.

Kemendikbud. 2014. Peraturan Menteri Pendidikan dan Kebudayaan, tentang Implementasi Kurikulum Pedoman Umum Pembelajaran. Nomor 81A, Tahun 2013

Morrison, T. J.; Stohlmann, M. \& Roehrig, G. H. 2012. Considerations for Teaching Integrated STEM Education. Journal of Pre-College Engineering Education Research (J-PEER): Vol. 2: Iss. 1, Article 4.

Muchsin, M. \& Khumaedi, K. 2017. Analisis keterampilan mahasiswa calon guru dalam menjelaskan konsep menggunakan analogi pada pembelajaran Fisika. Physics Communication, 1(1), 23-33.

NCTM. 2000. Principles and Standards for School Mathematics. American: Library of Congress Cataloguing in Publication.

Nur, Muhamad dan Wikandari, Prima Retno. 2008. Pengajaran Berpusat Kepada Siswa dan Pendekatan Konstruktivis dalam Pengajaran. Surabaya: Unesa University Press.

Patrick, 2000. Developing Critical Thinking. New York: Longman

Syakur, A. 2020. The Effect of Project Based Learning (PjBL) Continuing 
Learning Innovation on Learning Outcomes of English in Higher

Education. Budapest International Research and Critics in Linguistics and Education (BirLE) Journal, 625-630

Siswono, Tatag Yuli Eko. 2006. Desain Tugas untuk Mengidentifikasi Kemampuan Berpikir Kreatif Siswa dalam Matematika. Jurnal. (Online).

Tantri, Ari Atriya.2015. Implementasi Pendekatan Saintitifk Untuk Meningkatkan Hasil Belajar Siswa Pada Materi Sistem Transportasi Manusia Kelas VIII SMPN Tanjung Anom. Skripsi tidak diterbitkan. Surabaya : Universitas Negeri Surabaya

Wena, Made. 2013. Strategi Pembelajaran Inovatif Kontemporer. Jakarta: PT Bumi. 